Vol. 2, No. 2, 2020

Research Article

\title{
Workplace Spirituality, Work-Family Conflict, Perceived Organizational Support and Employee Well-Being among Hotel Employees
}

\author{
Hadziroh Ibrahim*, Nabilah Asyikin Mohd Noor Shatri and Md. Lazim Mohd Zin \\ Universiti Utara Malaysia, Sintok, Kedah, Malaysia \\ hadziroh@uum.edu.my; nabilahmns@gmail.com; lazim@uum.edu.my \\ *Correspondence: hadziroh@uum.edu.my
}

Received: 19 $9^{\text {th }}$ December 2019; Accepted: $2^{\text {nd }}$ April 2020; Published: $1^{\text {st }}$ May 2020

Abstract: The main purpose of this study is to investigate the factors influencing employee well-being among employees. Specifically, the study is conducted to examine the relationships between workplace spirituality, workfamily conflict, perceived organizational support, and employee well-being among hotel's employees in Perak, Malaysia. A total of $\mathbf{1 4 0}$ questionnaires were used for data analysis. Pearson correlation analysis shows that workplace spirituality and perceived organizational support have positive relationships to employee well-being, and work-family conflict has a negative relationship to employee well-being. Based on multiple regression analysis, the study found that two independent variables, which are workplace spirituality and work-family conflict, have significant relationships with employee well-being among hotel's employees. Meanwhile, perceived organizational support have no significant relationship with employee well-being. The implications and limitations of the study are also presented

Keywords: employee well-being; perceived organizational support; work-family conflict; workplace spirituality

\section{Introduction}

The implications of employee well-being to organizational performance and success, received a growing research attention from scholars (De Cuyper, Van der Heijden, \& De Witte , 2011; Taris \& Schreurs, 2009). This is due to the importance of employees' well-being for organizational quality, performance, business effectiveness and profit. Therefore, many organizations have implemented various programs to gain the benefits from having a high level of employee well-being. When employee feel well-being at work, they are more committed to their jobs and lead to produce high impact productivity.

In Malaysia, research on employee well-being in hotel's industry is still scant but there are still evidences reported constantly the issues of employee well-being among hotel's employees at Malaysia like stress of workload. As reported from other country, hotel managers experienced high level of stress, such as $23 \%$ represented the interpersonal tension and $20 \%$ stress from work overloads (O'Neill \& Davis, 2011). This can be assumed that hotel managers at Malaysia as well may face the same situations. Undoubtedly, this may lead to poor quality services and indirectly will affect the organizational effectiveness. In order to 
achieve an excellence quality service, the organization have to focus on their employee well-being. Therefore, identifying the factors influencing employee well-being among hotel's employees is needed to maintain employee performance for advancing hotel's industry growth in Malaysia.

One of the factors that can influence employee well-being is workplace spirituality (Sheep, 2006). It has been recommended, influenced on employee well-being as it has "potentially strong relevance to the well-being of individuals, organizations, and societies" (Sheep, 2006). Vasconcelos (2018) noted that Malaysia has a research output for workplace spirituality theory with only $2.6 \%$, which one of the research concerns of the role doubts and it is effectiveness, from 19 countries researched during the period of analysis. Therefore, inserting workplace spirituality in this research as predictor to enrich the theory within Malaysia context. Other than that, work-family conflict is widely mentioned in the employee well-being literature. Previous study has revealed a negative outcome on the quality of work and family and wellbeing in a general with these types of stress (Frone, Russell and Cooper, 1992). This is might due to a rise number of dual-earner households and rise in number of families who with dependent family members and who with single parent family (José Aurelio, José María, \& Antonio Rafael, 2017). Furthermore, many studies also reported the impacts of perceiving organizational support in order to enhance employee wellbeing. The importance of perceived organizational support toward employee well-being shows how much employee is admit and care of their well-being from organization (Al-Homayan, Shamsudin, Subramaniamn and Islam, 2013). Getting support from people surroundings including, family, friends, coworkers or even supervisor and organization, make an individual feel being care and love.

Till date, there is limited study that has been conducted precisely to identify the determinants of employee well-being among hotel's employees in Malaysia. Hence, this study attempts to examine the relationships between workplace spirituality, work-family conflict, perceived organizational support, and employee well-being among employees. This study intends to contribute to the existing knowledge base from Malaysian perspective.

\section{Literature Review}

\subsection{Workplace Spirituality and Employee Well-Being}

Well-being is defined as psychological, social and physical resources gained by an individual in order to meet their psychological, social and/or physical obstacles (Dodge, Daly, Huyton, \& Sanders, 2012). It means when an individual has sufficient resources from challenges happened, they will get along with the challenges and diminish it slowly, and vice versa. Furthermore, definition of employee well-being by Grawitch, Gottschalk, and Munz (2006) in terms of "mental health, physical health, motivation, stress, job satisfaction, commitment, climate and morale". This gives a meaning that employee well-being is consisted of various conditions to represent well-being. Some relate it with meaningful ness of the work (Ahmed, Majid \& Zin, 2016). Although generally well-being is being the basic theory to referred, there is still others using "affective well-being" to indicate an individual level of well-being, which being composed from three dimensions, which are anxious-contended, displeased-pleased and depressed-enthusiastic by Warr (1987 \& 1990). Most of researchers looking back to Warr (1987) and definition of employee well-being from Grant, Christianson, and Price (2007) as a whole through their experience and functioning at work.

According to Warr, Allan, and Birdi (1999), he noted that higher level of employee well-being is significant to greater job performance, reduced employee intention to turnover, lower absenteeism, and more positive behavior exhibit. These supported with Wright and Huang (2012) studied, which employee well-being is associated with employee retention, sick days, customer engagement, profitability, number of work outcomes that important, quality defects, performance of job, absenteeism and accidents at working place. Vasconcelos (2013) defined spirituality as a universal strength that activated that make inner life of an individual is put into action. In the context of organization, spirituality in the workplace context giving a meaning that applying virtues and intellectual skills for increasing experience for both oneself and 
people surroundings that rely on individual effort. Moreover, Scholars Dehler and Welsh (1994), define spirituality is something that will stimulate an action which is, it is a forms of work sensation to an individual. While, Mitroff and Denton (1999), defined spirituality as an individual's life goal to search for and also as to have and create an exclusive relationship with an individual's personal belief and the organizational value.

Arnetz, Ventimiglia, Beech, Demarinis, Lökk and Arnetz (2013) stated that employees will undermine workplace stress and promoting mental well-being when utilized their spiritual in the workplace. According to Sprung, Sliter and Jex (2012) they noted spirituality might be correlated with benefits in wellbeing and work outcomes. In spite of that, Badrinarayanan and Madhavaram (2008) show workplace spirituality drive spiritual well-being of salespeople that later rise their job satisfaction and commitment, and the consequences of performing an ethical behavior. Thus, we proposed the following hypothesis:

H1: There is a positive and significant relationship between workplace spirituality and employee well-being.

\subsection{Work-Family Conflict and Employee Well-Being}

Work-family conflict is defined as a cause of some compliments for career-oriented men that mutually incomparable for work demand and family which form to inter-role conflict Higgins \& Duxbury, 1992). Inter-role conflict lies whenever two or more roles held by an individual, where conflict can make an individual do own perceptions to another individual who negatively affected from their work performance (Robbins \& Judge, 2013). Other researcher, giving a definition to work-family conflict as a "form of interrole conflict in which the role pressures from work and family domains are mutually incomparable in some respect. That is, participation in work (family) role is made more difficult by virtue of participation in family (work) role" (Jeffrey H Greenhaus \& Beutell, 1985).

Frone et al., (1992) in their research shows that there is negative outcome from these types of stress, regarding to work-family conflict, towards work-family quality and well-being in broad. Furthermore, Carlson, Grzywacz and Zivnuska (2009) analyzed work-family conflict as comprised of employee wellbeing, morale and behaviors. Work-family conflict connected to well-being, health and organizational impact where supportive working environment changes and likeable to work-family relationship, gain a proactive role of employees with good societal results as well as the employment (Kossek, Lewis, \& Hammer, 2010). Drummond, O'Driscoll, Brough, Kalliath, Siu, Timms and Lo (2017) noted that there are diverse kind of support for different kind of people alleviate work-family conflict, and therefore increase psychological well-being, work attitude and health of employees. Thus, we proposed the following hypothesis:

H2: There is a negative and significant relationship between work-family conflict and employee well-being.

\section{Method}

The sample consisted of respondents belonging to few hotels in Perak, Malaysia. Data were collected by visiting the hotels in person. The convenience sampling technique was adopted to identify the hotels for this study. The sample includes employees from different departments such as finance, housekeeping, public area, steward, kitchen, waterpark, retail and recreation. Participation for this study was on voluntary basis and respondents were asked not to disclose their identities so that their identities are kept anonymous.

The study both adopted and adapted existing validated scales. All items were measured using sevenpoint Likert scales, which ranged from 'strongly disagree' to 'strongly agree'. The dependent variable of this study, employee well-being was measured by adopting seven items from Metcalfe et al., (2008). For workplace spirituality, we adopted the measurement items used by Ashmos and Duchon (2000). It consists of 16 items. To assess work-family conflict, a scale developed by Netemeyer et al., (1996) was used which has a total of ten items. To measure perceived organizational support, we adopted the measurement items 
used by Eisenberger et al., (1986) and Lambert (2000). A total of nine items are operationalized on perceived organizational support.

\section{Results}

\subsection{Respondents' profile}

Out of 220 survey questionnaires distributed, 175 responses were received. Finally, responses from 140 questionnaires were used for the data analysis. Out of these 140 questionnaires, 57.10 percent were female respondents and the rest were male respondents (42.90 percent); 98.6 percent were Malay; and majority of the respondents (50 percent) were aged group of 18-30 years. In total, 27.1 percent correspond to the SPM and Diploma, 25 percent to the undergraduate degree, 9.3 percent and 11.4 percent to the postgraduate degree and others. Respondents' current work position is also obtained, where 45 respondents were from non-management position, 25 respondents were managerial management, 36 respondents were lower management, and six respondents were from top management. While, majority of the respondents have been working with current organization and had working experience from 1-10 years. Table 1 shows the demographic information of the respondents

Table 1: Respondent's Profile

\begin{tabular}{|c|c|c|c|}
\hline Respondent's Profile & & Frequency & Percentage $(\%)$ \\
\hline \multirow[t]{2}{*}{ Gender } & Male & 60 & 42.90 \\
\hline & Female & 80 & 57.10 \\
\hline \multirow[t]{4}{*}{ Race } & Malay & 138 & 98.60 \\
\hline & Chinese & 1 & 0.70 \\
\hline & Indian & 0 & 0.00 \\
\hline & Others & 1 & 0.70 \\
\hline \multirow[t]{4}{*}{ Marital status } & Single & 68 & 48.60 \\
\hline & Married & 71 & 50.70 \\
\hline & Divorced & 1 & 0.70 \\
\hline & Others & 0 & 0.00 \\
\hline \multirow[t]{4}{*}{ Age } & 18 - 30 years old & 70 & 50.00 \\
\hline & $31-40$ years old & 46 & 32.90 \\
\hline & $41-50$ years old & 21 & 15.00 \\
\hline & More 50 years old & 3 & 2.10 \\
\hline \multirow[t]{5}{*}{ Degree or level of education } & SPM & 38 & 27.10 \\
\hline & Diploma & 38 & 27.10 \\
\hline & Undergraduate & 35 & 25.00 \\
\hline & Postgraduate & 13 & 9.30 \\
\hline & Others & 16 & 11.40 \\
\hline \multirow[t]{5}{*}{ Current work position } & Top Management & 6 & 4.30 \\
\hline & Middle Management & 36 & 25.70 \\
\hline & Lower Management & 28 & 20.00 \\
\hline & Managerial Management & 25 & 17.90 \\
\hline & Non-Management & 45 & 32.10 \\
\hline \multirow[t]{4}{*}{ Years with current organization } & $1-10$ years & 117 & 83.60 \\
\hline & $11-20$ years & 12 & 8.60 \\
\hline & $21-30$ years & 10 & 7.10 \\
\hline & More than 30 years & 1 & 0.70 \\
\hline \multirow[t]{4}{*}{ Years working experience } & $1-10$ years & 99 & 70.70 \\
\hline & $11-20$ years & 28 & 20.00 \\
\hline & $21-30$ years & 11 & 7.90 \\
\hline & More than 30 years & 2 & 1.40 \\
\hline
\end{tabular}

$N=140$ 


\subsection{Descriptive analysis}

The Statistical Package for Social Sciences (SPSS) was used for data analysis. Table 2 presents the mean and standard deviation for all the variables. The idea of obtain mean and standard deviation in descriptive statistics is to identify the central value of each variables and also spreading the values approximately at central tendency. Martey (2014) noted the value of both mean and standard deviation is important because it will include to significance of construct that being assessed. Before the result is obtained, all reverse code questions have been reversed in order to achieve one positive direction of that variable. Workplace spirituality with mean value of 5.49, perceived organizational support with mean value of 5.12, and employee well-being with mean value of 5.48. But for work-family conflict, the value of mean is the lowest among other variables and the value only at moderate level in seven-point Likert Scale.

Table 2: Descriptive Analysis

\begin{tabular}{lll}
\hline Variable & Mean & Standard Deviation \\
\hline Workplace Spirituality & 5.49 & 0.60 \\
Work-Family Conflict & 3.08 & 1.21 \\
Perceived Organizational Support & 5.12 & 0.75 \\
Employee Well-Being & 5.48 & 0.63 \\
\hline N $=140$ & \\
Independent Variables: Workplace Spirituality, Work-Family Conflict and Perceived Organizational Support \\
Dependent Variable: Employee Well-Being
\end{tabular}

Sekaran and Bougie (2010), noted that reliability analysis is done to identify the goodness of measures. Table 3 shown that work-family conflict has an excellent reliability coefficient of 0.94 for this study. Workplace spirituality and perceived organizational support relatively high reliability coefficient of 0.89 and 0.79 respectively. However, employee well-being is a relatively moderate reliability coefficient of 0.62 .

Table 3: Results of Reliability Analysis

\begin{tabular}{llll}
\hline Variable & Number of Items & Cronbach's Alpha & Level of Reliability \\
\hline Workplace Spirituality & 16 & 0.89 & High reliability \\
Work-Family Conflict & 10 & 0.94 & Excellent reliability \\
Perceived Organizational Support & 9 & 0.79 & High reliability \\
Employee Well-Being & 7 & 0.62 & Moderate reliability \\
\hline
\end{tabular}

Independent Variables: Workplace Spirituality, Work-Family Conflict and Perceived Organizational Support

Dependent Variable: Employee Well-Being

\subsection{Pearson Correlation}

To examine the direction of relationship between variables, Pearson's correlation analysis is employed. Table 4, show the correlation analysis outputs of variables varied out in this study. It shown that independent variable of workplace spirituality has correlation with dependent variable of $r=0.28$. While independent variable of work-family conflict with dependent variable has a correlation of $r=-0.27$.

Table 4: Pearson Correlation Analysis

\begin{tabular}{lllll}
\hline & WS & WFC & POS & EWB \\
\hline Workplace Spirituality (WS) & 1 & & & \\
Work-Family Conflict (WFC) & $-0.17^{*}$ & 1 & 1 & 0.14 \\
Perceived Organizational Support (POS) & $0.39^{* *}$ & -0.06 & $-0.27^{* *}$ & \\
Employee Well-Being (EWB) & $0.28^{* *}$ & & & \\
\hline${ }^{* *}$ Correlation is significant at the 0.01 level (2-tailed) & & & \\
${ }^{*}$ Correlation is significant at the 0.05 level (2-tailed) & & &
\end{tabular}


Lastly the independent variable of perceived organizational support has correlation with employee well-being with $\mathrm{r}=0.14$. The findings also revealed that all variables have a weak relationship with dependent variable according to Davis (1971) interpretation. Further, the results also reported a negative relationship between work-family conflict and employee well-being.

\subsection{Multiple Regression}

Table 5 shows the $\mathrm{R}$ square of 13 percent. It means that only 13 percent variance of employee wellbeing can be explained by the variables of the study and 87 percent from other that are not included in this study. To examine the relationship between workplace spirituality, work-family conflict and perceived organizational support to employee well-being, multiple regression analysis is used. In Table 6, there are two independent variables that have significant relationships with dependent variable, which are workplace spirituality with $p$-value of $0.02(\mathrm{p}<0.05)$ and work-family conflict with $p$-value of $0.01(\mathrm{p}<0.05)$. While perceived organizational support has no significant relationship with dependent variable ( $\mathrm{p}>0.05)$. Therefore, $\mathrm{H} 1$ and $\mathrm{H} 2$ were accepted.

Table 5: Model Summary

\begin{tabular}{llll}
\hline $\mathbf{R}$ & R Square $\left(\mathbf{R}^{2}\right)$ & Adjusted R Square & Std. Error of the Estimate \\
\hline $0.36^{\mathrm{a}}$ & 0.13 & 0.11 & 0.59 \\
\hline
\end{tabular}

Predictors: (Constant), Workplace Spirituality, Work-Family Conflict, Perceived Organizational Support

Dependent Variable: Employee Well-Being

Table 6: Multiple Linear Regression Analysis

\begin{tabular}{|c|c|c|c|c|c|}
\hline & \multirow{2}{*}{\multicolumn{2}{|c|}{ Unstandardized Coefficients }} & \multirow{3}{*}{$\begin{array}{c}\begin{array}{c}\text { Standardized } \\
\text { Coefficients }\end{array} \\
\text { Beta }\end{array}$} & \multirow{3}{*}{$\mathbf{t}$} & \multirow{3}{*}{ Sig. } \\
\hline & & & & & \\
\hline & B & Std. Error & & & \\
\hline (Constant) & 4.40 & 0.54 & & 8.16 & 0.00 \\
\hline Workplace Spirituality & 0.23 & 0.09 & 0.22 & 2.47 & 0.02 \\
\hline Work-Family Conflict & -0.12 & 0.04 & -0.23 & -2.83 & 0.01 \\
\hline Perceived Organizational Support & 0.03 & 0.07 & 0.04 & -0.51 & 0.61 \\
\hline
\end{tabular}

Dependent Variable: Employee Well-Being

\section{Discussion and Conclusion}

The main objective of the study is to examine the relationships between workplace spirituality, workfamily conflict, perceived organizational support, and employee well-being. The results show that workplace spirituality and work-family conflict have significant relationships with employee well-being. While, no significant relationship was found between perceived organizational support, and employee well-being.

Undoubtedly, workplace spirituality can boost up the well-being of employee at work place (Badrinarayan, 2016 \& Sheep, 2006). For the sake of communities and organizations, Krishnakumar and Neck, (2002) insisted that spirituality's assistance for employee well-being is important to increased joy, satisfaction of job and responsibility (Fry, 2005; Paloutzian, Emmons, \& Keortge, 2003; Reave, 2005). At hotel industry, workplace spirituality is important to enhance employee well-being to satisfied employee with needs provided, later they performed at their best and increasing organization performance. Employee at hotel experience community at work because they meet people most every time, which needs of affection and recognition brings joy and happiness for them. Experiencing meaning at work is important as well, not only in hotel industry. Feels of meaning at work making an individual to set their own goals for a better future. Setting the goals is the consequences after employee experience a positive meaning at work. This will lead to an individual feeling ease and increasing their well-being too. 
Furthermore, work-family conflict may lead to conflict due to workloads, less supportive working environment, low salary and others. These factors are all triggered the works role, effecting conflict rise at home. Simultaneously, when family matters such as childcare, household or financial stability, may influence the rise of conflict at work place. At hotel industry, not all employees are capable to handle conflict at both roles, roles at workplace and roles in a family at the same time. As hotel employees are busy with their tasks, due to services provided to customer whole time, they do not have much time to recover the roles in short time and this later influence another domain. Hence, it influenced an individual wellbeing's level that created either positive or negative outcome of their well-being such as increase absenteeism in reasons of tired playing both roles in the same time. Therefore, work-family conflict influenced hotel employee well-being.

Theoretically, this study offered useful knowledge for future research. The results show that there are two factors that influence employee well-being, there are workplace spirituality and work-family conflict. It can be concluded that the impacts of these two factors on employee well-being indirectly will increase employee's performance and motivation, and further will enhance overall organizational performance and effectiveness.

Practically, management of hotel industry should focus on the issues of workplace spirituality and work-family conflict among employees and take appropriate actions to overcome these two problems. For example, organization should implement a flexible working environment that meets employees need, to increase the workplace spirituality of an employee. Other than that, management would look into a familyfriendly program such as, provide nursery to their employees' child at workplace, so the employees can look their child when lunch time and this might influence employee well-being.

The main limitation of the study is about sample size. Due to the time constraint, the researchers only can access few hotels operating in Perak, Malaysia. A diverse sample of employee's hotel from different state could provide better understanding of the research model. The scope of this research can be further extended in future. More research using other variables including moderating and mediating variables is recommended.

\section{References}

Al-Homayan, A.M., Shamsudin, F.M., Subramaniam, C. and Islam, R. (2013). The moderating effects of organizational support on the relationship between job stress and nurses' performance in public sector hospitals in Saudi Arabia. Advances in Environmental Biology, 7(9), 2606-2617.

Ahmed, U., Majid, A. H. A., \& Zin, M. L. M. (2016). Meaningful work and work engagement: A relationship demanding urgent attention. International Journal of Academic Research in Business and Social Sciences, 6(8), 116-122.

Alimo-Metcalfe, B., Alban-Metcalfe, J., Bradley, M., Mariathasan, J., \& Samele, C. (2008). The impact of engaging leadership on performance, attitudes to work and wellbeing at work: A longitudinal study. Journal of Health, Organisation and Management, 22(6), 586-598.

Amstad, F. T., Meier, L. L., Fasel, U., Elfering, A., \& Semmer, N. K. (2011). A Meta-Analysis of Work-Family Conflict and Various Outcomes With a Special Emphasis on Cross-Domain Versus Matching-Domain Relations. Journal of Occupational Health Psychology, 16(2), 151-169.

Ariza-Montes, A., Arjona-Fuentes, J. M., Law, R., \& Han, H. (2017). Incidence of workplace bullying among hospitality employees. International Journal of Contemporary Hospitality Management, 29(4), 1116-1132.

Arnetz, B. B., Ventimiglia, M., Beech, P., Demarinis, V., Lökk, J., \& Arnetz, J. E. (2013). Spiritual values and practices in the workplace and employee stress and mental well-being. Journal of Management, Spirituality and Religion, 10(3), 271-281.

Ashmos, D. P., \& Duchon, D. (2000). Spirituality at Work: A Conceptualization and Measure. Journal of Management Inquiry, 9(2), 134-145.

Badrinarayanan, V., \& Madhavaram, S. (2008). Workplace Spirituality and the Selling Organization: A Conceptual Framework and Research Propositions. Journal of Personal Selling E Sales Management, 28(4), 421-434. 
Caesens, G., Stinglhamber, F., \& Ohana, M. (2016). Perceived organizational support and well-being: a weekly study. Journal of Managerial Psychology, 31(7), 1214-1230.

Carlson, D. S., Grzywacz, J. G., \& Zivnuska, S. (2009). Is work-family balance more than conflict and enrichment? Human Relations, 62(10), 1459-1486.

Cartwright, S., \& Cooper, C. L. (2009). The Oxford Handbook of Organizational Well Being. In The Oxford Handbook of Organizational Well Being.

Chaudhry, M. S., Sohail, F., \& Riaz, N. (2013). Impact of Employee Relation on Employee Performance in Hospitality Industry of Pakistan. Entrepreneurship and Innovation Management Journal, 1(1), 60-72.

Danna, K. and Griffin, R. W. (1999). Health and well-being in the workplace: a review and synthesis of the literature. Journal of Management, 25(3), 357-384.

Davis, J. A. (1971). Elementary survey. Englewood Cliffs, New Jersey: Prentice Hall.

De Cuyper, N., Van der Heijden, B.I.J.M. and De Witte, H. (2011). Associations between perceived employability, employee well-being, and its contribution to organizational success: a matter of psychological contracts? The International Journal of Human Resource Management, 22(7), 1486-1503.

Department of Statistics, M. (n.d.). Services. Retrieved June 15, 2019, from Department of Statistics, Malaysia website: https://www.dosm.gov.my/v1/index.php?r=column/ctwoByCat\&parent_id=108\&menu_id=b0pIV1E3RW40VWR TUkZocEhyZ1pLUT09

Department of Statistics Malaysia. (2012). Keluaran Dalam Negeri Kasar pada Harga Malar - Suku Kedua 2013. Retrieved from http://www.statistics.gov.my/portal/images/stories/files/LatestRele ases/gdp/Constant_Q2_2013.pdf

Drummond, S., O’Driscoll, M. P., Brough, P., Kalliath, T., Siu, O. L., Timms, C., Lo, D. (2017). The relationship of social support with well-being outcomes via work-family conflict: Moderating effects of gender, dependants and nationality. Human Relations, 70(5), 544-565.

Eisenberger, R., Huntington, R., Hutchison, S., \& Sowa, D. (1986). Perceived Organizational Support. 71(3), $500-507$.

Frone, M. R., Russell, M., \& Cooper, M. L. (1992a). Antecedents and Outcomes of Work-Family Conflict: Testing a Model of the Work-Family Interface. Journal of Applied Psychology, 77(1), 65-78.

Frone, M. R., Russell, M., \& Cooper, M. L. (1992b). Prevalence of work-family conflict: Are work and family boundaries asymmetrically permeable? Journal of Organizational Behavior, 13(7), 723-729.

Hartline, M. D., \& Jones, K. C. (1996). Employee performance cues in a hotel service environment: Influence on perceived service quality, value, and word-of-mouth intentions. Journal of Business Research, 35(3), 207-215.

Hu, B. A., \& Cai, L. A. (2004). Hotel Labor Productivity Assessment. Journal of Travel E Tourism Marketing, 16(2-3), 2738.

José Aurelio, M.-G., José María, B.-F., \& Antonio Rafael, R.-R. (2017). Relationship between work-family balance, employee well-being and job performance. Academia Revista Latinoamericana de Administración, 30(1), 40-58.

Karakas, F. (2010). Spirituality and performance in organizations: A literature review. Journal of Business Ethics, 94(1), 89-106.

Kossek, E. E., Lewis, S., \& Hammer, L. B. (2010). Work-life initiatives and organizational change: Overcoming mixed messages to move from the margin to the mainstream. Human Relations, 63(1), 3-19.

Krejcie, R. V., \& Morgan, D. W. (1970). Determining Sample Size for Research Activities. Educational and Psychological Measurement, 30(3), 607-610.

Kurtessis, J.N., Eisenberger, R., Ford, M.T., Buffardi, L.C., Stewart, K.A. and Adis, C. S. (2015). Perceived organizational support a Meta-analytic evaluation of organizational support theory. Journal of Management, 43(6), 1854-1884.

Lai, I. (2013). Malaysia is 10th most visited country. Retrieved August 19, 2019, from The Star Online website: http://www.thestar.com.my/News/Nation/2013/08/06/Malaysia-is- 10th-most-visited-country.aspx/

Lambert, S. J. (2000). Added benefits: The link between work-life benefits and organizational citizenship behavior. Academy of Management Journal, 43(5), 801-815.

Lim, J. (2019). Tough times in hospitality industry. Retrieved June 21, 2019, from The Star Online website: https://www.thestar.com.my/metro/metro-news/2019/05/23/tough-times-in-hospitality-industry

Malaysia Productivity Corporation. (2017). 24th productivity report 2016/2017. Petaling Jaya: MPC.

Marriot. (2015). Marriot international recognized for outstanding work-life. Retrieved July 14, 2019, from http://news.marriott.com/2015/02/marriott-international-recognized-for-outstanding-work-life-programs/

Martey, A. M. (2014). IPv6 acceptance in U.S. enterprise networks: An investigation with structural equation modeling (Doctoral dissertation, Capella University). 
Mashal Ahmed, W., Shuming, Z., \& Meng, X. (2018). Perceived organizational support and employee well-being: Testing the mediatory role of work-family facilitation and work-family conflict. Chinese Management Studies, 12(2), 469-484.

Netemeyer, R. G., Boles, J. S., \& McMurrian, R. (1996). Development and validation of work-family conflict and familywork conflict scales. Journal of Applied Psychology, 81(4), 400-410.

O'Neill, J. W., \& Davis, K. (2011). Work stress and well-being in the hotel industry. International Journal of Hospitality Management, 30(2), 385-390.

Sekaran, U., \& Bougie, R. (2010). Research methods for business: A skill-building approach (5th edition). Haddington: John Wiley \& Sons.

Sheep, M. L. (2006). Nurturing the whole person: The ethics of workplace spirituality in a society of organizations. Journal of Business Ethics, 66(4), 357-375.

Sprung, J. M., Sliter, M. T., \& Jex, S. M. (2012). Spirituality as a moderator of the relationship between workplace aggression and employee outcomes. Personality and Individual Differences, 53(7), 930-934.

Szamosi, L. T. (2006). Just what are tomorrow's SME employees looking for? Education and Training, 48(8/9), 654-665.

Taris, T. W. and Schreurs, P. J. G. (2009). Well-being and organizational performance: an organizational- level test of the happy-productive worker hypothesis. Work E Stress, 23(2), 120-136.

Tourism Malaysia. (2017). Key Performance Indicator 2017. Retrieved June 12, 2019, from Tourism Malaysia website: http://mytourismdata.tourism.gov.my/wp-content/uploads/2019/02/key-performance-indicator-2017.pdf

Vandenberghe, C. (2011). Workplace spirituality and organizational commitment: An integrative model. Journal of Management, Spirituality and Religion, 8(3), 211-232.

Vasconcelos, A. F. (2018). Workplace spirituality: empirical evidence revisited. Management Research Review, 41(7), 789821.

Wilson, R. (2018). Poor workplace wellbeing causes decrease in productivity for $63 \%$ of employees, research finds. Retrieved July 14, 2019, from Talint International website: https:/www-recruitment--international-couk.cdn.ampproject.org/v/s/www.recruitment-international.co.uk/blog/2017/08/poor-workplace-wellbeingcauses-decrease-in-productivity-for-54-percent-of-employees-researchfinds.amp?usqp=mq331AQDoAEK\&amp is $\mathrm{v}=0.1$ \#hea 